\title{
Biological activities of isolated phenolic compounds from Trachelospermum asiaticum var. intermedium nakai
}

\author{
Ui-Tea Yun ${ }^{1}$, Ju-Young Cho ${ }^{1}$, Eun-Young Jeong ${ }^{1}$, Jae-Bum Jo ${ }^{1}$, Eun-Ho Lee ${ }^{1}$, \\ Byung-Oh Kim ${ }^{1}$, Young-Je Cho ${ }^{1,2 *}$ \\ ${ }^{1}$ School of Food science and Biotechnology, Kyungpook National University, Daegu 41566, Korea \\ ${ }^{2}$ Food and Bio-Industry Research Institute, Kyungpook National University, Daegu 41566, Korea
}

\section{마삭줄(Trachelospermum asiaticum var. intermedium nakal)로부터 추출한 pheonolic compounds의 생리활성}

\author{
윤의태 ${ }^{1} \cdot$ 조주영 ${ }^{1} \cdot$ 정은영 $^{1} \cdot$ 조재범 ${ }^{1} \cdot$ 이은호 $^{1} \cdot$ 김병오 $^{1} \cdot$ 조영제 $^{1,2 *}$ \\ ${ }^{1}$ 경북대학교 식품공학부, ${ }^{2}$ 식품생물산업연구소
}

\begin{abstract}
This study provided the evidence activity for biological of phenolic compounds from Trachelospermum asiaticum var. intermedium nakaier as a beauty food. The contents of phenolic compounds in water and $70 \%$ ethanol extracts were $16.8 \mathrm{mg} / \mathrm{g}$ and $38.1 \mathrm{mg} / \mathrm{g}$, respectively. DPPH free radical scavenging activities of water and ethanol extracts at $100 \mu \mathrm{g} / \mathrm{mL}$ of phenolic concentration were $80.9 \%$ and $83.1 \%$, respectively. ABTS radical decolorization activity was $95.0 \%$ in water extracts and $95.8 \%$ in ethanol extracts at $200 \mu \mathrm{g} / \mathrm{mL}$ phenolic concentration. Antioxidant protection factor (PF) was determined to 2.43 and $2.45 \mathrm{PF}$ in water extracts and ethanol extracts at $100 \mu \mathrm{g} / \mathrm{mL}$ phenolic concentration. TBARs of water and ethanol extracts were $89.9 \%$ and $89.3 \%$ each at $200 \mathrm{\mu g} / \mathrm{mL}$ phenolic concentration. The inhibitory effect of ethanol extracts at $200 \mu \mathrm{g} / \mathrm{mL}$ phenolic concentration on xanthine oxidase was $50.5 \%$. The inhibitory activity of a-glucosidase was $92.6 \%$ in ethanol extracts at $200 \mu \mathrm{g} / \mathrm{mL}$ phenolic concentration. As a result, this study will provide valuable information as a functional material with antioxidant activity, inhibitory activities of xanthin oxidase and a-glucosidase.
\end{abstract}

Key words : antioxidant, xanthin oxidase, a-glucosidase, health food, Trachelospermum asiaticum

\section{서 론}

식품의 기능은 여러 가지가 있지만 일반적으로 3가지로 분류할 수 있다. 식품의 1 차적 기능은 영양 기능으로 식품의 영양소를 신체의 구성성분 및 에너지원으로 이용하고, 2차 적 기능은 감각기능으로 식품의 맛, 향기, 물성 등이 풍요로 운 식생활을 즐길 수 있게 하며, 3 차적 기능은 생리 조절기 능으로 식품 중에 있는 여러 생리활성 성분이 생체를 조절

*Corresponding author. E-mail : yjcho@knu.ac.kr

Phone : 82-53-950-7755, Fax : 82-53-950-7762

Received 1 February 2017; Revised 2 March 2017; Accepted 3 March 2017.

Copyright (c) The Korean Society of Food Preservation. All rights reserved.
함으로써 질병예방과 건강향상에 도움을 준다(1). 과거에 는 1,2 차적 기능 위주의 식생활이었다면, 현대사회는 기술 이 발달되면서 생활수준이 향상되고 건강에 대한 관심이 증가하여 3 차적 기능의 식품 수요가 높아져 건강 증진을 목적으로 하는 기능성 식품이 등장하게 되었다(2).

기능성 식품이란 알레르기 면역력을 향상시키는 생체방 어기능, 당뇨병과 같은 질병의 예방과 회복기능, 소화 기능 조절 등의 생체리듬의 조절기능, 과산화지방 생성억제 등 의 노화억제기능 등이 있다(3).

기능성 식품은 활성산소를 감소시킴으로써 질병의 예방 과 생체조절 기능을 할 수 있도록 도와준다(4). 활성산소는 우리 몸 내부에서 섭취한 영양소가 에너지를 생성하는 과정 에서 생긴 부산물이며 대부분 미토콘드리아에서 생성된다 (5). 또한 활성산소는 우리 몸 내부에 세균이나 바이러스와 
같은 유해성분이 들어오거나 고강도의 운동을 하는 등 체내 의 항산화 방어계의 균형이 깨졌을 때 주로 생성된다 $(6,7)$. 활성산소생성 반응은 연쇄적으로 일어나며 체내에서 활성 산소는 계속하여 생산된다. 활성산소의 연쇄적 반응을 억 제하기 위해서는 활성산소를 조절하는 항산화제가 필요하 다(8). 식물은 산화적인 손상으로부터 자신을 보호하기 위 해 다양한 phytochemical을 생산하는 것으로 알려져 있다 (9). 대부분의 약리식물들은 폴리페놀 화합물을 많이 함유 하고 있는데, 이러한 다양한 종류의 페놀성 화합물은 천연 항산화제 또는 항암효과 등의 다양한 생리활성을 나타내고 있어 많은 관심을 모으고 있다(10).

협죽도과(Apocynaceae)에 속하는 마삭줄(Trachelospermum asiaticum var. intermedium Nakai)은 바위나 나무위에 기어 오르는 상록활엽의 덩굴성 수목으로 길이는 $5 \mathrm{~m}$ 에 이르며, 한방에서는 7월에 열매를 채취하여 절골통치료에 사용하 거나 가을에 잎을 채취하여 수분을 스며들게 한 후 햇볕에 말려 거풍, 지혈, 비통, 토혈 등에 달여 복용한다(11). 마삭 줄, 고련피, 희첨 복합 추출물이 항알러지와 항염증에 효과 가 있다는 연구결과(12)는 알려져 있지만 마삭줄의 그 외 생리활성에 관한 연구는 아직까지 미비하다.

본 연구에서는 천연 기능성 소재로서의 마삭줄의 항산 화 효과와 항통풍, 항당뇨 실험을 통해 마삭줄의 기능성 식품으로 활용하기 위한 기초자료를 검토하였다.

\section{재료 및 방법}

\section{실험 재료}

본 연구에서 사용한 마삭줄(Trachelospermum asiaticum var. intermedium Nakai)은 2014년 지리산 지역에서 재배된 것을 시중에서 유통되는 것을 구입하여 사용하였다. 시료 는 실온 그늘에서 건조시킨 후 $40 \mathrm{mesh}$ 로 분말화하여 $4^{\circ} \mathrm{C}$ 에 서 보관하며 시료로 사용하였다.

마삭줄 추출물의 제조

시료 추출은 물 추출물의 경우 건조 마삭줄 분말시료 $1 \mathrm{~g}$ 에 증류수 $200 \mathrm{~mL}$ 를 가하고 용액이 $100 \mathrm{~mL}$ 가 될 때 까지 가열하여 증발시킨 후 냉각하여 24시간 동안 상온에 서 교반 추출하였으며, ethanol 추출물은 시료 $1 \mathrm{~g}$ 에 $70 \%$ ethanol $100 \mathrm{~mL}$ 를 추출용매로 가하여 24시간 동안 상온에 서 교반 추출하였다. 추출액은 Whatman No. 1 filter paper (Whatman, Maidstone, UK)로 여과한 후 $4^{\circ} \mathrm{C}$ 저온고에서 보관하며 시료로 사용하였다.

Total phenolic compounds의 함량 측정

Total phenolic compounds 함량 측정은 Folin과 Denis의 방법(13)에 준하여 측정하였으며, 시료 $1 \mathrm{~mL}$ 에 $95 \%$ ethanol $1 \mathrm{~mL}$ 와 증류수 $5 \mathrm{~mL}$ 를 첨가하고 $1 \mathrm{~N}$ Folin-Ciocalteu
reagent(Junsei, Tokyo, Japan) $0.5 \mathrm{~mL}$ 를 넣어 잘 섞어주고, 5 분간 방치한 후, $5 \% \mathrm{Na}_{2} \mathrm{CO}_{3} 1 \mathrm{~mL}$ 를 가한 후, 흡광도 725 $\mathrm{nm}$ 에서 1 시간 이내에 측정하여 gallic acid를 이용한 표준 곡선으로부터 양을 환산하였다(Total phenolic compounds content in gallic acid(10-200 $\mathrm{\mu g} / \mathrm{mL})$ was calculated using the following equation based on the calibration curve: $y=0.0101 x-0.0403, R^{2}=0.996$, where $y$ was the absorbance, and $\mathrm{x}$ was the gallic acid equivalent $(\mu \mathrm{g} / \mathrm{mL})$.

\section{Free radical 소거반응(DPPH) 측정}

a,a-diphenyl- $\beta$-picrylhydrazyl(DPPH) radical에 대한 소거 능력은 Blois의 방법(14)에 준하여 측정하였다. 시료의 phenolic compounds 농도를 $50,100,150,200 \mu \mathrm{g} / \mathrm{mL}$ 로 맞추 어 각 시료 $1 \mathrm{~mL}$ 에 $60 \mu \mathrm{M} \mathrm{DPPH} 3 \mathrm{~mL}$ 를 넣고 vortex한 후 15 분 동안 방치한 다음 $517 \mathrm{~nm}$ 에서 흡광도를 측정하였 다. DPPH radical에 대한 소거능은 1-(반응구의 흡광되대조 구의 흡광도 $) \times 100$ 으로 나타내었다.

\section{ABTS radical cation decolorization 측정}

$\mathrm{ABTS}$ radical cation decolorization의 측정은 Pellegrini의 방법(15)에 준하여 측정하였다. $7 \mathrm{mM} \mathrm{ABTS} 5 \mathrm{~mL}$ 과 140 $\mathrm{mM} \mathrm{K} \mathrm{K}_{2} \mathrm{~S}_{2} \mathrm{O}_{8} 88 \mu \mathrm{L}$ 를 섞어 어두운 곳에 16 시간 이상 방치한 용액 $1 \mathrm{~mL}$ 와 ethanol $88 \mathrm{~mL}$ 를 혼합한 $\mathrm{ABTS}$ solution 1 $\mathrm{mL}$ 를 $50,100,150,200 \mu \mathrm{g} / \mathrm{mL}$ 의 phenolic compounds 농도 를 가지는 시료용액 $50 \mu \mathrm{L}$ 와 혼합하여 30 초간 진탕한 후 2 분 30 초간 incubation하고 $734 \mathrm{~nm}$ 에서 흡광도를 측정하였 다. ABTS radical cation decolorization 효과는 1-(반응구의 흡광도/대조구의 흡광도) $\times 100$ 으로 나타내었다.

\section{Antioxidant protection factor(PF) 측정}

$\mathrm{PF}$ 는 Andarwulan과 Shetty의 방법(16)에 준하여 측정하 였다. $10 \mathrm{mg}$ 의 $\beta$-carotene $/ 50 \mathrm{~mL}$ chloroform 용액 $1 \mathrm{~mL}$ 를 evaporator용 수기에 넣고 $40^{\circ} \mathrm{C}$ water bath에서 chloroform을 증류시킨 후, $20 \mu \mathrm{L}$ linoleic acid, $184 \mu \mathrm{L}$ Tween 40 과 50 $\mathrm{mL} \mathrm{H}_{2} \mathrm{O}_{2}$ 를 가하여 emulsion을 만들고, $5 \mathrm{~mL}$ 의 emulsion을 $50,100,150,200 \mu \mathrm{g} / \mathrm{mL}$ 의 phenolic compounds 농도를 가지 는 시료용액 $100 \mu \mathrm{L}$ 에 혼합하여 잘 섞어준 뒤 $50^{\circ} \mathrm{C}$ 에서 30 분간 반응시켜 냉각시킨 다음, $470 \mathrm{~nm}$ 에서 흡광도를 측 정하였다. $\mathrm{PF}$ 는 (시료첨가구의 흡광도시료무첨가구의 흡 광도)의 비로 나타내었다.

Thiobarbituric acid reactive substances(TBARs) 측정

TBARs는 Burge와 Aust의 방법(17)에 준하여 측정하였 다. $1 \%$ linoleic acid와 $1 \%$ tween 40 으로 emulsion을 만들었 다. Emulsion $0.8 \mathrm{~mL}$ 와 50, 100, $150,200 \mathrm{\mu g} / \mathrm{mL}$ 의 phenolic compounds 농도를 가지는 시료 $0.2 \mathrm{~mL}$ 를 섞은 후 $50^{\circ} \mathrm{C}$ water bath에서 8 시간 반응시켰다. 반응액에 TBA/TCA 시 
약 $4 \mathrm{~mL}$ 를 넣고 15 분간 끓인 후 10 분 동안 냉각시킨 다음 $2,000 \mathrm{rpm}$ 으로 20 분간 원심분리 하였다. 원심분리 후 상등 액을 $532 \mathrm{~nm}$ 에서 흡광도를 측정하였다. TBARs radical 소 거능은 1-(반응구의 TBARs $\mu \mathrm{M} /$ 대조구의 TBARs $\mu \mathrm{M}$ ) $\times 100$ 으로 나타내었다.

\section{통풍(Gout) 억제 효과 측정}

Xanthine oxidase 활성저해 측정법은 Stirpe와 Corte의 방 법(18)에 준하여 측정하였다. 반응구는 $0.1 \mathrm{M}$ potassium phosphate buffer(pH 7.5)에 $2 \mathrm{mM}$ xanthine을 녹인 기질액 $3 \mathrm{~mL}$ 에 효소액 $0.1 \mathrm{~mL}$ 와 $50,100,150,200 \mu \mathrm{g} / \mathrm{mL}$ 의 phenolic compounds 농도를 가지는 각 시료용액 $0.3 \mathrm{~mL}$ 를 넣고 대조 구에는 추출용액 대신 증류수를 $0.3 \mathrm{~mL}$ 첨가하여 $37^{\circ} \mathrm{C}$ 에서 30 분간 반응시키고 $20 \%$ trichloroacetic acid(TCA) $1 \mathrm{~mL}$ 를 가하여 반응을 종료시킨 다음 원심 분리하여 단백질을 제거 한 후 반응액 중에 생성된 uric acid를 흡광도 $292 \mathrm{~nm}$ 에서 측정하여, uric acid를 사용한 표준곡선으로 환산, 정량한 후 percentage inhibition(\%)을 구하였다. Percentage inhibition (\%)은 1-(반응구의 uric acid의 양/대조구의 uric acid의 양) $\times 100$ 으로 나타내었다.

\section{a-Glucosidase 저해효과 측정}

a-Glucosidase 저해 활성은 Tibbot 등의 방법(19)에 준하 여 측정하였다. 혼합액 $100 \mathrm{~mL}$ sodium succinate buffer(pH 6.8)에 4-nitrophenyl a-D-glucopyranoside를 $0.152 \mathrm{~g}$ 용해시 켜 기질을 만들었다. 효소액 $0.1 \mathrm{~mL}$ 를 $37^{\circ} \mathrm{C}$ water bath에서 10 분간 반응시키고 $50,100,150,200 \mu \mathrm{g} / \mathrm{mL}$ 의 phenolic compounds 농도를 가지는 시료 $0.1 \mathrm{~mL}$ 와 기질 $2 \mathrm{~mL}$ 를 넣어 $37^{\circ} \mathrm{C}$ water bath에서 20 분간 반응시켰다. 대조구는 증 류수 $0.1 \mathrm{~mL}$ 를 사용하였다. 반응시킨 후 종료시약으로 $5 \%$ $\mathrm{Na}_{2} \mathrm{CO}_{3} 3 \mathrm{~mL}$ 를 넣은 후 $470 \mathrm{~nm}$ 에서 흡광도를 측정하였다.

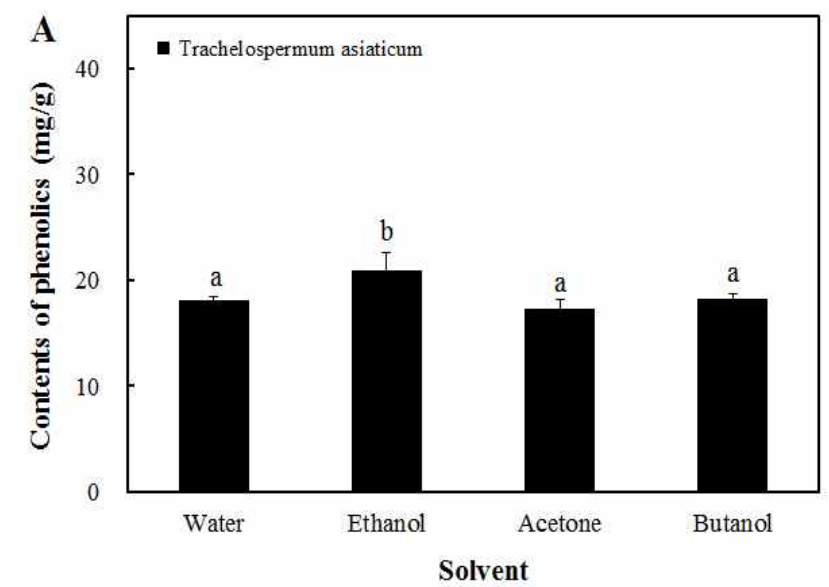

이때 생성된 p-nitrophenol(PNP)은 다음의 식으로 저해율을 구하였다. 저해율(\%)은 [1-(반응구의 PNP 생성량/대조구의 PNP 생성량)] $\times 100$ 으로 나타내었다.

\section{통계처리}

모든 실험은 3 회 이상 반복 측정하였고 자료의 통계처리 는 IBM SPSS statistics ver. 22 for windows(IBM Corp., Armonk, New York, NY, USA)를 이용하여 평균 \pm 표준편차 (mean $\pm \mathrm{SD}$ )로 표시하였고 분산분석(ANOVA)과 Duncan's multiple range test를 실시하여 시료간의 유의차를 $\mathrm{p}<0.05$ 수준으로 비교 분석하였다.

\section{결과 및 고찰}

용매 종류 및 용매농도가 phenolic compounds의 용 출 함량에 미치는 영향

Phenolic compounds는 식물의 방어기작에 의하여 생산 되는 1,000 여 가지의 2 차 대사산물 중 한 종류이고 benzene 고리에 $-\mathrm{OH}$ 기 여러 개가 치환되어있는 천연 항산화제로 널리 알려져 있다(20,21). 또한 phenolic hydroxyl기에 의해 단백질 등의 거대 분자들과 결합하는 특성을 가지고 있어 항산화, 항암, 항당뇨 등의 생리기능을 나타낸다고 알려져 있다(22). 본 연구에서는 마삭줄 추출물에 포함되어 있는 phenolic compounds의 성분 함량의 최적조건을 알아보기 위하여 용매별, 농도별로 조제하고 추출수율을 측정하였 다. 마삭줄의 용매별 추출은 water, ethanol, acetone, butanol을 $100 \%$ 농도로 추출하였다. 용매별로 추출한 결과, Fig. $1 \mathrm{~A}$ 에 서와 같이 water, ethanol, acetone, butanol 순으로 18.08, $20.87,17.20,18.20 \mathrm{mg} / \mathrm{g}$ 의 용출량을 나타내었으며, ethanol 추출물에서 $20.87 \mathrm{mg} / \mathrm{g}$ 로 가장 높은 함량을 나타냈다. 식품

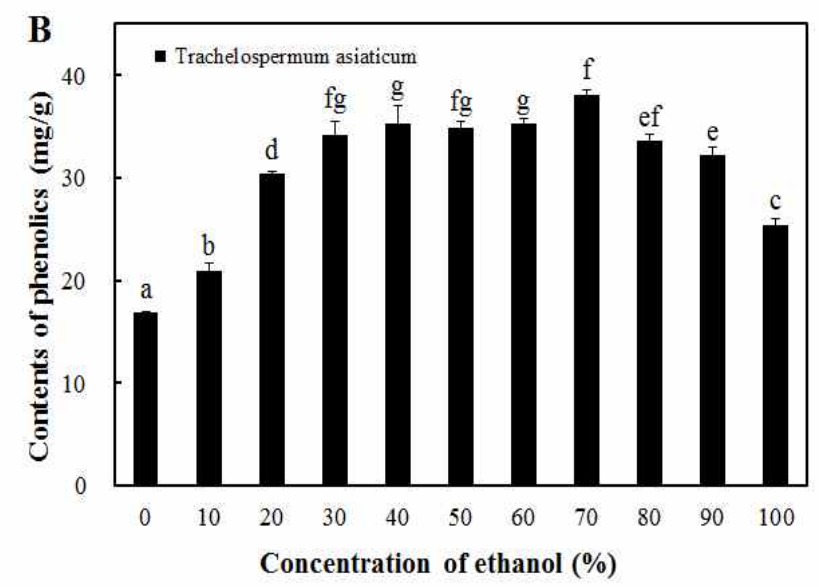

Fig. 1. The content of phenoilc compounds in the effect of various solvents (A) and ethanol concentration (B) on extraction of phenolic from Trachelospermum asiaticum extracts.

Values with different alphabet in the column were significantly different among group at $\mathrm{p}<0.05$ level by a Duncan's multiple range test. 
에 적용이 가능한 ethanol을 이용하여 $10-100 \%$ 의 농도로 추출하여 최적 phenolic compounds의 용출 조건을 알아보 았다. 그 결과 Fig. $1 \mathrm{~B}$ 와 같이 $70 \%$ ethanol 추출물에서 $38.10 \mathrm{mg} / \mathrm{g}$ 으로 가장 높은 phenolic compounds의 용출량을 나타내었다. 건강기능성 식품으로의 가능성을 확인하기 위 해서 안정성이 높은 물과 ethanol을 이용하여 실험을 진행 하였다. 마삭줄의 물 추출물과 phenolic compounds 용출량 이 가장 높았던 $70 \%$ ethanol 추출물을 $50,100,150,200$ $\mu \mathrm{g} / \mathrm{mL}$ 의 특정 농도로 설정하여 시료로 사용하였다.

\section{마삭줄 추출물의 항산화 활성}

DPPH는 ascorbic acid, tocopherol, polyhydroxy 방향족 화합물, 아민류에 의해서 환원되어 보라색이 탈색됨으로써 항산화 물질의 전자 공여능을 측정할 때 사용되며, 전자공 여 작용은 산화성활성 free radical에 전자를 공여하여 산화 를 억제시키는 척도가 된다(23). 마삭줄 추출물은 $100 \mu$ $\mathrm{g} / \mathrm{mL}$ phenolics 농도를 기준으로 Table 1 과 같이 물과 $70 \%$ ethanol 추출물의 radical 소거능은 $80.9 \%$ 와 $83.1 \%$ 로 나타내 어, 물 추출물보다 $70 \%$ ethanol 추출물에서 radical 소거능이 더 높은 것을 확인할 수 있었다. $\operatorname{Kim}(24)$ 은 병솔 꽃나무 가지를 70\% ethanol로 추출하여 $100 \mathrm{\mu g} / \mathrm{mL}$ 농도로 $\mathrm{DPPH}$ 를 측정한 결과, $83 \%$ 의 radical 소거능을 나타내어 마삭줄과 비슷한 효능을 나타내었다. Hong 등(25)은 흰씀바귀고채 뿌리의 물 추출물을 $125 \mathrm{\mu g} / \mathrm{mL}$ 농도로 $\mathrm{DPPH}$ 를 측정한 결과, $9 \%$ 의 radical 소거능을 나타내었고, $2,000 \mathrm{\mu g} / \mathrm{mL}$ 농도 에서 $91 \%$ 의 radical 소거능을 나타내었다. 이러한 결과에 따라 마삭줄 추출물은 저농도에서도 높은 radical 소거효과
를 가짐을 알 수 있었다.

ABTS radical 소거능은 ABTS와 potassium persulfate를 암실에 방치하였을 때 ABTS+ radcal이 생성되고, 시료의 항산화력에 의해 ABTS+ radical이 제거되어 radical 특유의 색인 청록색이 탈색되는 것을 이용한 방법이다(26). 마삭줄 의 물과 70\% ethanol 추출물을 phenolic compounds 농도를 $50,100,150,200 \mu \mathrm{g} / \mathrm{mL}$ 으로 조절하여 ABTS radical 소거능 을 측정한 결과, Table $1 \mathrm{~B}$ 에서와 같이 물 추출물은 최소 $36.28 \%$ 에서 최대 $94.98 \%$ 의 $\mathrm{ABTS}$ 소거능을 나타내었고 $70 \%$ ethanol의 경우, 최소 $37.54 \%$ 에서 최대 $95.84 \%$ 의 ABTS 소거능을 나타내었다. Positive control인 BHT의 경 우, 마삭줄 추출물과 동일 농도에서 최대 $70.27 \%$ 의 소거능 을 나타내었고, $\operatorname{Ham}(27)$ 의 백합나무 변재와 심재 아세톤 추출물의 ABTS radical 소거능을 측정한 결과, $10 \mu \mathrm{g} / \mathrm{mL}$ 의 농도에서 $6 \%$ 와 $26 \%, 50 \mathrm{\mu g} / \mathrm{mL}$ 의 농도에서 $7 \%$ 와 $35 \%$ 의 ABTS radical 소거능을 나타내어 마삭줄 추출물은 표준 항산화제와 또 다른 천연물에 비해 ABTS radical 소거능이 더 우수한 것을 확인할 수 있었다.

마삭줄 추출물의 phenolic compounds 농도를 50,100 , $150,200 \mathrm{\mu g} / \mathrm{mL}$ 으로 설정하여 $\mathrm{PF}$ 의 차이를 측정한 결과, Table $1 \mathrm{C}$ 에서와 같이 물 추출물의 경우 $2.29-2.51 \mathrm{PF}, 70 \%$ ethanol 추출물의 경우 2.15-2.63 PF를 나타내었다. 위의 결과에서는 물 추출물과 $70 \%$ ethanol 추출물이 큰 차이를 보이지 않는다고 판단했다. $\mathrm{Bang}(28)$ 의 청일뽕 오디 $80 \%$ ethanol 추출물은 $1.46 \mathrm{PF}$ 의 결과를 나타내었다는 보고 에 비교하면, 마삭줄 $70 \%$ ethanol 추출물은 $2.15 \mathrm{PF}$ 이상의 결과를 보여 보다 높은 $\mathrm{PF}$ 측정 결과를 확인할 수 있었고,

Table 1. Antioxidant activity of DPPH, ABTS, Antioxidant protection factor and TBARs on water and 70\% ethanol extract from Trachelospermum asiaticum.

\begin{tabular}{|c|c|c|c|c|c|c|}
\hline & \multirow{3}{*}{$\begin{array}{l}\text { Antioxidant } \\
\text { assay }\end{array}$} & \multirow{3}{*}{ Extracts } & \multicolumn{4}{|c|}{ Antioxidant activity } \\
\hline & & & \multicolumn{4}{|c|}{ Phenolic compounds concentration $(\mu \mathrm{g} / \mathrm{mL})$} \\
\hline & & & 50 & 100 & 150 & 200 \\
\hline \multirow{3}{*}{ A } & \multirow{3}{*}{$\begin{array}{c}\mathrm{DPPH} \\
(\%)\end{array}$} & Water & $76.40 \pm 0.91^{\text {al) }}$ & $80.88 \pm 0.72^{\mathrm{b}}$ & $83.87 \pm 0.59^{\mathrm{c}}$ & $85.36 \pm 0.34^{d}$ \\
\hline & & Ethanol & $80.66 \pm 0.34^{\mathrm{a}}$ & $83.05 \pm 0.34^{b}$ & $85.29 \pm 0.47^{\mathrm{c}}$ & $87.08 \pm 0.34^{\mathrm{d}}$ \\
\hline & & $\mathrm{BHT}^{2)}$ & $56.31 \pm 0.78^{\mathrm{a}}$ & $70.80 \pm 0.68^{b}$ & $73.94 \pm 0.13^{\mathrm{c}}$ & $74.01 \pm 0.22^{\mathrm{c}}$ \\
\hline \multirow{3}{*}{ B } & \multirow{3}{*}{$\begin{array}{l}\text { ABTS } \\
(\%)\end{array}$} & Water & $36.28 \pm 0.62^{a}$ & $63.01 \pm 0.26^{b}$ & $81.94 \pm 0.63^{\mathrm{c}}$ & $94.98 \pm 0.40^{\mathrm{d}}$ \\
\hline & & Ethanol & $37.54 \pm 0.44^{\mathrm{a}}$ & $63.77 \pm 1.00^{\mathrm{b}}$ & $83.51 \pm 0.32^{\mathrm{c}}$ & $95.84 \pm 2.33^{\mathrm{d}}$ \\
\hline & & BHT & $22.88 \pm 2.07^{\mathrm{a}}$ & $46.68 \pm 2.17^{\mathrm{b}}$ & $56.72 \pm 2.87^{\mathrm{c}}$ & $70.27 \pm 3.05^{\mathrm{d}}$ \\
\hline \multirow{3}{*}{$\mathrm{C}$} & \multirow{3}{*}{$\begin{array}{l}\text { Antioxidant protection } \\
\text { factor }(\mathrm{PF})\end{array}$} & Water & $2.29 \pm 0.04^{\mathrm{a}}$ & $2.43 \pm 0.11^{b}$ & $2.49 \pm 0.03^{\mathrm{b}}$ & $2.51 \pm 0.07^{b}$ \\
\hline & & Ethanol & $2.15 \pm 0.05^{\mathrm{a}}$ & $2.45 \pm 0.05^{b}$ & $2.55 \pm 0.02^{\mathrm{c}}$ & $2.63 \pm 0.02^{\mathrm{d}}$ \\
\hline & & BHT & $2.86 \pm 0.02^{\mathrm{a}}$ & $3.04 \pm 0.02^{b}$ & $3.10 \pm 0.01^{\mathrm{c}}$ & $3.14 \pm 0.02^{\mathrm{d}}$ \\
\hline \multirow{3}{*}{ D } & \multirow{3}{*}{$\begin{array}{l}\text { TBARs } \\
(\%)\end{array}$} & Water & $43.88 \pm 4.88^{\mathrm{a}}$ & $70.44 \pm 0.35^{b}$ & $83.41 \pm 0.77^{c}$ & $89.94 \pm 1.43^{\mathrm{d}}$ \\
\hline & & Ethanol & $50.14 \pm 1.90^{\mathrm{a}}$ & $79.98 \pm 0.87^{b}$ & $87.91 \pm 1.05^{\mathrm{c}}$ & $89.34 \pm 1.63^{\mathrm{c}}$ \\
\hline & & BHT & $94.07 \pm 0.08^{\mathrm{a}}$ & $93.88 \pm 0.61^{\mathrm{a}}$ & $93.42 \pm 1.17^{\mathrm{a}}$ & $93.74 \pm 0.97^{\mathrm{a}}$ \\
\hline
\end{tabular}

\footnotetext{
${ }^{1)}$ Values with different alphabet in the column were significantly different among group at $\mathrm{p}<0.05$ level by a Duncan's multiple range test.

${ }^{2}$ BHT, positive control
} 
물질에 대한 PF가 1.2 이상이 되었을 때, 항산화 능력이 우수하다고 평가되는데(29), 마삭줄 추출물의 경우 지용성 물질에 대한 높은 $\mathrm{PF}$ 를 가진다고 확인할 수 있었다.

TBARs 값은 지방산패도를 나타내며, TBA 시약과 반응 하여 붉은색이 되는 malondialdehyde의 생성량을 나타낸 것이다(30). Table $1 \mathrm{D}$ 에서와 같이 $100 \mu \mathrm{gg} / \mathrm{mL}$ phenolic compounds 농도를 기준으로 물과 $70 \%$ ethanol 추출물의 TBARs값은 70\%와 80\%로 나타내었고, $200 \mu \mathrm{g} / \mathrm{mL}$ phenolic compounds 농도에서는 두 추출물 모두 $89 \%$ 의 높은 결과를 나타내었다. Kim 등(31)은 호두를 $60 \%$ ethanol로 추출하여 $200 \mu \mathrm{g} / \mathrm{mL}$ phenolic compounds 농도를 기준으로 TBARs값 을 측정하여 $75 \%$ 의 결과를 나타내었고, $\operatorname{Kim}(32)$ 은 머위 엽병을 $95 \%$ ethanol로 추출하여 $100 \mu \mathrm{g} / \mathrm{mL}$ 농도에서 $43.37 \%$ 의 측정 결과를 나타내었다고 보고한 것과 비교하면 마삭줄의 지질과산화 억제효과가 더 큰 것으로 확인되었 다. 이러한 결과로 보아 마삭줄 추출물은 수용성 및 지용성 물질에 대하여 높은 항산화 활성을 나타내었으며, 추출물 의 phenolic compounds에 농도 의존적인 양상을 나타내는 것으로 확인되었다.

\section{통풍(Gout) 억제 효과 측정}

Xanthine oxidase(Xoase)는 purine 대사에 관여하는 효소 이고 xanthine 또는 hypoxanthine으로부터 산소를 떼어내고 과산화수소와 uric acid를 만들어 낸다. 형성된 uric acid는 혈장 내에서 증가되고, 침상모양의 결정이 골절에 축적되 어 심한 통증을 유발하는 통풍(gout)과 신장에 침착되어 신장질환을 일으키는 효소로 알려져 있다(33). 마삭줄의 물과 $70 \%$ ethanol 추출물을 $50-200 \mu \mathrm{g} / \mathrm{mL}$ 의 phenolic compounds 농도로 첨가하여 xanthine oxidase 저해 효과를 측정하였다. 마삭줄 추출물의 xanthine oxidase 저해 활성은 물 추출물에 비해 $70 \%$ ethanol 추출물에서 억제효과가 높은 것을 알 수 있었으며, phenolic compounds의 농도 의존적으 로 저해 효과가 높아지는 것을 확인할 수 있었다. 현재 시중 에서 통풍 치료제로 사용되고 있는 allopurinol(34)은 Fig. 2 에서와 같이 $200 \mu \mathrm{g} / \mathrm{mL}$ 의 phenolic compounds 농도에서 $52.7 \%$ 의 억제효과를 나타내었는데, 마삭줄 $70 \%$ ethanol 추 출물은 이와 비슷한 수준인 $50.52 \%$ 의 억제력을 나타내어 통풍 치료제로서 활용이 가능할 것으로 판단되었다. $\operatorname{Kim}(35)$ 은 댕댕이덩굴 물 추출물을 $1,000 \mu \mathrm{g} / \mathrm{mL}$ phenolic compounds의 농도로 측정한 결과, $8.33 \%$ 저해 효과를 나타 내었고, Yoon 등(36)의 미숙, 완숙 뜰보리수 추출물은 1,000 $\mathrm{\mu g} / \mathrm{mL}$ 의 농도에서 $30.0 \%, 28.2 \%$ 의 xanthine oxidase 저해 효과를 나타내었고, $\mathrm{Cho}(37)$ 는 $70 \%$ ethanol 감국 추출물에 서는 $51.12 \%$ 의 저해 효과를 나타내었다고 보고하였다. 위 의 결과들과 비교하였을 때 마삭줄의 xanthine oxidase 저해 효과가 매우 우수한 것으로 확인되었다.

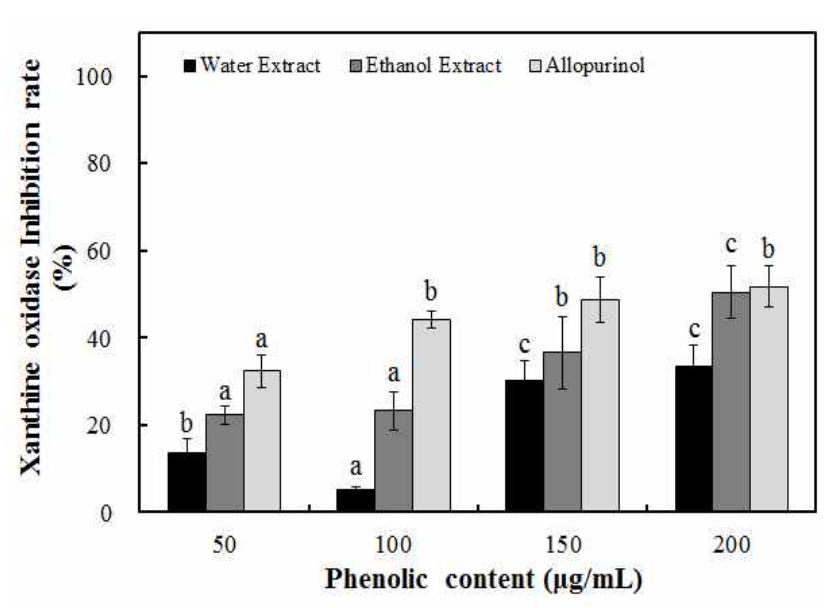

Fig. 2. Inhibition effects of water and ethanol extracts from Trachelospermum asiaticum on xanthine oxidase.

Values with different alphabet in the column were significantly different among group at $\mathrm{p}<0.05$ level by a Duncan's multiple range test.

$a-G u c o s i d a s e$ 저해효과 측정

a-glucosidase는 과당류 등과 결합해 단당류로 분해시키 는 작용을 하여 탄수화물의 소화에 중요한 역할을 하므로 a-glucosidase의 저해가 식후 고혈당 방지에 도움이 되며, 생체 내 음식과 같이 투여되었을 때 a-glucosidase 저해제들 은 당류들의 소화를 저해하여 소장에서 소화를 지연시켜 식후 혈당치의 증가를 낮춰준다(38). 마삭줄 추출물의 a -glucosidase 저해 효과 측정 결과, Fig. 3 에서와 같이 물 추출물에서는 저해 효과가 나타나지 않았으나 $70 \%$ ethanol 추출물에서는 $100 \mathrm{\mu g} / \mathrm{mL}$ phenolic compounds 농도에서 $82.6 \%$ 저해효과를 나타내었으며, phenolic compounds 농도 가 증가할수록 농도 의존적으로 저해 효과가 증가하여 200 $\mu \mathrm{g} / \mathrm{mL}$ phenolic compounds 농도에서 $92.6 \%$ 의 저해 효과를 나타내었다. $\operatorname{Sin}(39)$ 은 노랑느타리버섯을 12 시간 물 추출 하여 a-glucosidase 저해 효과를 측정한 결과, $80 \%$ 의 저해

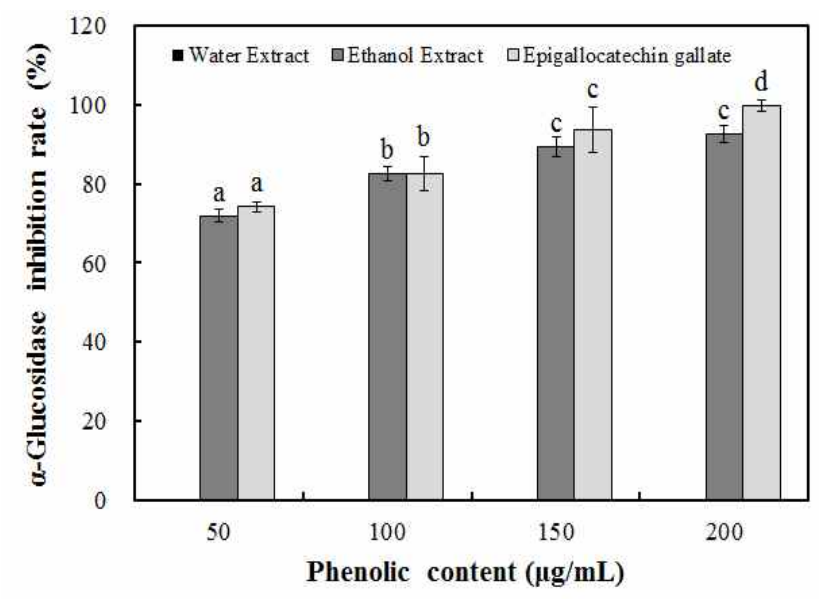

Fig. 3. Inhibition effects of ethanol extracts from Trachelospermum asiaticum on a-glucosidase.

Values with different alphabet in the column were significantly different among group at $p<0.05$ level by a Duncan's multiple range test. 
효과를 나타내었고, Son(40)은 구지뽕나무 뿌리 추출물을 $300 \mu \mathrm{g} / \mathrm{mL}$ 농도에서 측정한 결과, $77 \%$ 의 저해 효과를 나타 내었다. Kim(41)등은 Ecklonia cava, Eisenia bicyclis, Sargassum thunbergii를 $1,000 \mu \mathrm{g} / \mathrm{mL}$ 농도로 측정한 결과, 98\% 저해 효과가 나타나 마삭줄 추출물의 a-glucosidase 저해 효과는 저농도에서도 보다 우수한 저해 효과를 가진다 고 확인할 수 있었다.

위의 결과들로 미루어 보았을 때 마삭줄 추출물 항산화 효과, 통풍 억제 및 항당뇨 효과를 가진 건강 기능성 식품으 로서 적용 가능성을 기대할 수 있었다.

\section{요 약}

본 연구에서 마삭줄(Trachelospermum asiaticum var. intermedium Nakar)을 용매별과 ethanol 농도별로 추출한 결과, 용매별 추출에서 ethanol 추출물이 $20.8 \mathrm{mg} / \mathrm{g}$ 으로 가 장 높은 phenolic compounds 용출량을 보였고, 농도별 추출 에서 $70 \%$ ethanol 추출물이 $38.1 \mathrm{mg} / \mathrm{g}$ 으로 가장 높았다. 물 추출물은 $16.8 \mathrm{mg} / \mathrm{g}$ 의 phenolic compounds 용출량을 보 였다. 마삭줄을 물과 ethanol을 추출용매로 사용하여 항산 화 효과와 항통풍 및 항당뇨 효과를 확인하여 건강 기능성 식품으로의 가능성을 증명 하고자 하였다. DPPH radical 소거능 측정 결과, $100 \mathrm{\mu g} / \mathrm{mL}$ phenolic compounds의 농도에 서 물 추출물은 $80.9 \%, 70 \%$ ethanol 추출물은 $83.1 \%$ 의 활성 을 나타내었다. ABTS radical 소거능 측정 결과 $200 \mu \mathrm{g} / \mathrm{mL}$ phenolic compounds의 농도에서 물 추출물은 $95.0 \%, 70 \%$ ethanol 추출물은 $95.8 \%$ 의 소거능력을 나타내었다. $\mathrm{PF}$ 측정 결과, $100 \mathrm{\mu g} / \mathrm{mL}$ phenolic compounds의 농도에서 물 추출물 은 $2.43 \mathrm{PF}, 70 \%$ ethanol 추출물에서는 $2.45 \mathrm{PF}$ 를 나타내었 다. TBARs 측정 결과, $200 \mu \mathrm{g} / \mathrm{mL}$ phenolic compounds의 농도에서 물과 $70 \%$ ethanol 추출물에서 $89.9 \%$ 와 $89.3 \%$ 의 활성을 나타내었다. 통풍 억제 효과 측정 결과, $200 \mathrm{\mu g} / \mathrm{mL}$ phenolic compounds의 농도에서 물 추출물은 $33.3 \%, 70 \%$ ethanol 추출물은 $50.5 \%$ 의 저해 효과를 나타내었다. a -glucosidase 저해 효과 측정 결과, 물 추출물에는 저해 효과 가 나타나지 않았고, $70 \%$ ethanol 추출물에서는 $200 \mathrm{\mu g} / \mathrm{mL}$ phenolic compounds의 농도에서 $92.6 \%$ 의 저해 효과를 나타 내었다. 이러한 결과들로 미루어 보았을 때 마삭줄 추출물 은 항산화 작용과 건강 기능성 식품으로 활용 가능성을 확인할 수 있었다.

\section{References}

1. Lee SM (2009) Study on the consumers' recognition of antioxidant health functional foods. MS Thesis, Chungang
University, Korea, p 60

2. Kang EJ (2011) Providing on food functionality information for improvement of consumers' understanding. Ph D Thesis, Duksung women's University, Korea, p 1

3. Jung SY (2005) Current status and prospect of functional food. MS Thesis, Chosun University, Korea, p 16

4. Joo SY (2013) Antioxidant activities of medicinal plant extracts. J Korean Soc Food Sci Nutr, 42, 512-519

5. Jang JB, Park OR, Yun TE (2010) Free radicals, physical performace, aging and antioxidants. Korean J Ideal Body Beauty, 2, 19-27

6. Cho YJ, Ju IS, Kwon OJ, Chun SS, An BJ, Kim JH (2008) Biological and antimicrobial activity of Portulaca oleracea. J Korean Soc Appl Biol Chem, 51, 49-54

7. Li HC, Yashiki S, Sonoda J, Lou H, Ghosh SK, Byrnes JJ, Lema C, Fujiyoshi T, Karasuyama M, Sonoda S (2000) Green tea polyphenols induce apoptosis in vitro in peripheral blood $\mathrm{T}$ lymphocytes of adult T-cell leukemia patients. Japan J Cancer Res, 91, 34-40

8. Lee JH (2011) Free radicals and disease. Kor J local community, 64, 106-113

9. Jo JO, Jung IC (2006) Phenolic compounds of Ligustrum japonicum Leaves. J Korean Soc Food Sci Nutr, 35, 713-720

10. Hertog ML, Kromhout D, Aravanis C, Blackburn H, Buzina R, Fidanza F, Giampaoli S, Jansen A, Menotti A, Nedeljkovic S, Pekkarinen M, Simic BS, Toshima H, Feskens EJM, Hollman PCH, Katan MB (1995) Flavonoid intake and long-term risk of coronary heart disease and cancer in the seven countries study. Arch Intern Med 155, 381-386

11. Choi MS (1999) Landscaping tree. Landscaping tree, 53, 11-12

12. Cosmeccakorea (2015) A composition comprising climbing begbane, melliaawadirachta and Siegesbeckiae Herba complex extract having efffects of anti-inflammation and anti-allergy. Korea Patent NO. 1020120115270

13. Folin O, Denis W (1912) On phosphotungsticphosphomolybdic compounds as color reagents. J Biol Chem, 12, 239-243

14. Blios MS (1958) Antioxidant determinations by the use of a stable free radical. Nature, 181, 1199-1200

15. Fellegrini N, Ke R, Yang M, Rice-Evans C (1999) Screening of dietary carotenoids and carotenoid-rich fruit extracts for antioxidant activities applying 2,2'-azinobis (3-ethylenebenzothiazoline-6-sulfonic acid) radical 
cation decolorization assay. Methods Enzymol, 299, 379-389

16. Andarwulan N, Shetty K (1999) Phenolic content in differentiated tissue cultures of untransformed and Agrobacterium-transformed roots of anise (Pimpinella anisum L.). J Agric Food Chem. 47, 1776-1780

17. Buege JA, Aust SD (1978) Microsomal lipid peroxidation. Methods Enzymol, 52, 302-310

18. Stirpe F, Corte ED (1969) The regulation of rat liver xanthine oxidase. J Biol Chem, 244, 3855-3863

19. Tibbot BK, Skadsen RW (1996) Molecular cloning and characterization of a gibberellin-inducible, putative a -glucosidase gene from berley. Plant Mol Biol, 30, 229-241

20. Choi YM, Kim MH, Shin JJ, Park JM, Lee JS (2003) The antioxidant activities of the some commercial teas. J Korean Soc Food Sci Nutr, 32, 723-727

21. Han HM (2009) Change of antioxidant activity of wheat flour dough with the addition of phenolic compounds at the different baking process. MS Thesis, Keimyung University, Korea, p 9

22. Nam JH (2004) Analysis of phenolic compounds and antioxidant activities of water extracts from Zizypus jujuba. MS Thesis, Keimyung University, Korea, p 8

23. Kim SJ (2004) DPPH radical scavenging and ACE inhibitory effects of the aerial parts of Fagopyrum esculentum and isolation of flavonoids. MS Thesis, Sunchon National University, Korea, p 52

24. Kim JH (2010) Identification of compounds with elastase inhibition and DPPH radical scavenging activities from Callistemon lanceolatus. MS Thesis, Jeju National University, Korea. p 46-48

25. Hong SG, Jeong DM, Kim KY, Hwang EH (2010) The composition of the root of Lxeris dentata var. albiflora Nakai. and cell viability and DPPH radical scavenging activities of its extract. Korean J Nutr, 43, 105-113

26. Jang JY (2016) Functional activity and volatile flavor compounds analysis of Korean red wine. MS Thesis, The Catholic University of Korea, Korea, p 43

27. Ham SG (2012) Investigation of biological activity of leaf from Liriodendron tulipifera L.. MS Thesis, Yeungnam University, Korea, p 30

28. Bang IS (2008) Physicochemical characteristics and physiological activities of the Chongilppong mulberry. $\mathrm{Ph}$ D Thesis, Kongju National University, Korea, p 112
29. Kim JS, Lee JY, Park KT, An BJ, Lee SH, Cho YJ (2013) The biological activity from Prunella vulgaris extracts. Korean J Food Preserv, 20, 234-241

30. Kim JH, Lee SY, Kwon OJ, Park JH, Lee JY (2013) Anti-aging and anti-diabetes effects of Aconitum pesudo-laeve var. erectum extracts. J Life Sci, 23, 616-621

31. Kim MK, Kim JS, Cho BS, Kim JH, Lee IC, Lee MS, Cho YJ (2011) Functional properties of walnut in cosmetics. J Life Sci, 21, 858-864

32. Kim MY (2009) Isolation and identification of antioxidant substances from the stems of butterbur (Petasites japonicus). MS Thesis, Dong-A University, Korea, p 21

33. Kang YH, Park YK, Oh SR, Moon KD (1995) Studise of the physiological functionality of pine needle and mugwort extracts. Korean J Food Sci Technol, 27, 978-984

34. Kim KB, Jo BS, Park HJ, Park KT, An BJ, Ahn DH, Kim MU, Chae JW, Cho YJ (2012) Healthy functional food properties of phenolic compounds isolated from Ulmus pumila. Korean J Food Preserv, 19, 909-918

35. Kim JY (2016) A study on physiological activities of extracts from Cocculus trilobus stems. MS Thesis, Daegu Haany University, Korea, p 48-51

36. Yoon KY, Hong JY, Nam HS, Moon YS, Shin SR (2007) Antioxidant activities and xanthine oxidase inhibitory effects of hot-water extracts from fruits of Elaeagnus multiflora Thunb. in maturity. J Korean Soc Food Sci Nutr, 36, 14-19

37. Cho YJ (2014) Biological activity of extracts from Chrysanthemum incidicum Linne by ultrafine grinding.

J Korean Soc Food Sci Nutr, 43, 110-117

38. Choi HJ (2000) Inhibitory effect of Gyrophora esculenta on a-glucosidase. $\mathrm{Ph} \mathrm{D}$ Thesis, Kyunghee University, Korea, p 1-2

39. Sin JW (2015) Extraction of anti-diabetic a-glucosidase inhibitor from Pleurotus cornucopiae and Lentinus lepideus and demonstration of its anti-diabetic function. MS Thesis, Paichai University, Korea, p 6-8

40. Son HW (2012) Comparison of a-glucosidase inhibition by Cudrania tricuspidata. Kyungpook National University, Korea, p 9-23

41. Kim JH, Kang HM, Lee SH, Lee JY, Park LY (2015) Antioxidant and a-Glucosidase inhibition activity of seaweed extracts. Korean J Food Preserv, 22, 290-296 